\title{
Numerical modelling of combustion in SI engine fuelled with methane
}

\begin{abstract}
Results of numerical analysis of methane and gasoline combustion in multipoint ignition SI engine are presented in the paper. Work parameters of engine fuelled with methane lean mixtures of $\lambda=1.45$ and 1.8 for three configurations of spark plugs (one, two and four active spark plugs) are compared. These configurations were chosen taking into consideration earlier research concerning numerical modelling and experiments. The results of carried out analysis proved that using two spark plugs at air excess number $\lambda=1.8$ caused that engine work parameters are similar to case of mixtures of $\lambda=1.45$ with one spark plug configuration. Simultaneously, the emission of nitric oxide was decreased more than eight times and the concentration of carbon dioxide in exhaust gases was $20 \%$ lower.
\end{abstract}

Key words: multi-spark plug engine, methane, numerical modelling, lean mixture

\section{Modelowanie numeryczne procesu spalania w silniku ZI zasilanym metanem}

\begin{abstract}
W artykule przedstawiono wyniki analizy numerycznej procesu spalania metanu w silniku ZI z zaptonem wielopunktowym. Porównano parametry pracy silnika zasilanego ubogimi mieszankami metanu o $\lambda=1,45$ oraz 1,8 dla trzech konfiguracji świec zapłonowych: jedna, dwie oraz cztery pracujace świece zapłonowe. Konfiguracje te wybrano, biorac pod uwage wcześniejsze prace związane z modelowaniem oraz eksperymentem. Wyniki symulacji pokazały, że zastosowanie dwóch świec zapłonowych, przy współczynniku nadmiaru powietrza $\lambda=1,8$, dało zbliżone parametry pracy silnika w porównaniu do zasilania mieszanką o $\lambda=1,45$ z jedna świeca zapłonowa. Jednocześnie otrzymano ponad ośmiokrotnie mniejsza emisję tlenku azotu oraz zmniejszona o $20 \%$ zawartość dwutlenku węgla w spalinach modelu silnika.
\end{abstract}

Słowa kluczowe: silnik z zapłonem wielopunktowym, metan, modelowanie numeryczne, mieszanki ubogie

\section{Introduction}

Introducing more rigorous toxic components emission standards forces the piston engine design development. Lean mixture combustion can lead to efficient decrease in toxic component emission and increase in engine efficiency. However it is connected with problems such as decrease in flame propagation velocity or high level of engine work nonrepeatability. These inconveniencies can be partly overcome by applying multi-ignition among others $[12,13,19]$.

One of the research activities carried out in the Institute of Internal Combustion Engines and Control Engineering is $3 \mathrm{D}$ modelling of combustion in multipoint spark ignition engine fuelled with Lean mixtures of air excess factor $\lambda \leq 2.0[6,10]$ and modelling of spark ignition process [15-17]. The calculations are performer in KIVA-3V [2].

The paper aims at analysis of application of the multipoint ignition in stationary gaseous engines operating at constant rotational speed and driving electric generators. Such engines can be fuelled with natural gas, biogas (waste dump gas, sewage gas) or mine gas as well as fuels containing methane. The containment of methane in above mentioned fuels differs according to the origin of the fuel. The natural gas contains approx. $98 \%$ of methane, biogas contains approx. $40-60 \%$, and main gas obtained during the exploitation of the mine contains approximately $25-60 \%$ of methane [3]. The containment of methane in mine gas differs for different coal deposits, the way it is exploited and time [4].

The paper is the continuation of numerical analysis of combustion in multipoint ignition engine model fuelled with

\section{Wstęp}

Ciągłe zaostrzanie norm dotyczących składników toksycznych emitowanych przez silniki tłokowe wymusza zmiany w konstrukcji tych silników. Skuteczne obniżenie emisji powyższych składników spalin oraz zwiększenie sprawności silników ZI można uzyskać przez spalanie mieszanek zubożonych. Wiąże się to jednak z pewnymi problemami, takimi jak np. spadek szybkości rozprzestrzeniania się płomienia, czy też bardzo duża niepowtarzalność pracy silnika. Niedogodności te można częściowo zniwelować m.in. przez wprowadzenie właśnie zapłonu wielopunktowego $[12,13,19]$.

Jednym z kierunków badań Instytutu Maszyn Tłokowych i Techniki Sterowania Politechniki Częstochowskiej jest modelowanie 3D, przy wykorzystaniu programu KIVA$3 \mathrm{~V}$ [2], procesu spalania $\mathrm{w}$ silniku wieloświecowym zasilanym mieszankami ubogimi $(\lambda \leq 2,0)[6,10]$ oraz samego procesu wyładowania iskrowego [15-17].

Praca niniejsza ukierunkowana jest na analize przydatności wielopunktowego zapłonu w gazowych silnikach stacjonarnych pracujących przy niezmiennej prędkości obrotowej i napędzających agregaty prądotwórcze. Silniki te mogą być zasilane gazem ziemnym, biogazem (gaz wysypiskowy, biogaz z osadów ściekowych) lub gazem kopalnianym, czyli paliwami, których głównym składnikiem jest metan. Zawartość metanu w wymienionych paliwach zależy od ich pochodzenia. Gaz ziemny wysokometanowy zawiera ok. 98\% metanu, biogaz ok. 40-65\%, natomiast gaz kopalniany pozyskiwany $\mathrm{w}$ trakcie bieżącej eksploatacji zawiera ok. 25-60\% metanu [3]. Zawartość metanu w 
lean mixtures of gasoline [10]. This time the scope of the research is the application of multipoint ignition in engine fuelled with lean mixtures of methane and air and the impact of such approach on the emission of $\mathrm{NO}$ and $\mathrm{CO}_{2}$.

\section{Engine model S320ER}

The engine model was prepared according to the test engine data. The test engine was designed as the modified single-cylinder, high-pressure S320ER (WSW ANDORIA) engine, which has been rebuilt in order to apply multipoint spark ignition [11]. The main engine parameters are presented in Table 1.

Table 1. Main engine parameters

Tabela 1. Główne parametry silnika

\begin{tabular}{|l|c|}
\hline Engine capacity/objętość skokowa & $1810 \mathrm{~cm}^{3}$ \\
\hline Number of cylinders/liczba cylindrów & 1 \\
\hline Cylinder alignment/układ cylindra & Horizontal/poziomy \\
\hline Cylinder diameter/średnica cylindra & $120 \mathrm{~mm}$ \\
\hline Crank throw/promień wykorbienia & $80 \mathrm{~mm}$ \\
\hline Crankshaft length/dtugość korbowodu & $275 \mathrm{~mm}$ \\
\hline Piston stroke/skok tłoka & $160 \mathrm{~mm}$ \\
\hline Compression ratio/stopień sprężania & 8.5 \\
\hline Rotational speed/prędkość obrotowa & $1000 \mathrm{rpm}$ \\
\hline $\begin{array}{l}\text { Number of spark plugs/liczba świec } \\
\text { zapłonowych }\end{array}$ & 8 \\
\hline
\end{tabular}

The application of multipoint spark ignition in the test engine allowed to fuel the engine with lean mixtures of liquid and gaseous fuels of air excess factor $\lambda \leq 2.0[6,9]$. The location of spark plugs in the engine head is presented in Figure 1.

The numerical modelling was performed in KIVA-3V code [2]. The software enabled 3D modelling of flow in piston engine combustion chambers of various geometry with taking turbulence and heat exchange into consideration.

The geometric mesh (Fig. 2) describing the combustion chamber of the test engine was generated in the pre-processor of KIVA-3V package.

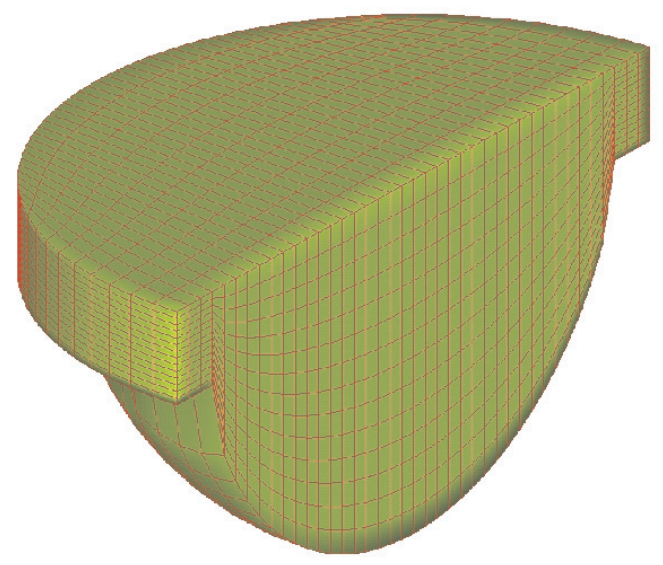

Fig. 2. Geometric mesh in cartesian co-ordinate system Rys. 2. Siatka geometryczna $w$ prostokątnym układzie wspótrzędnych gazie kopalnianym zależy od samego złoża węgla, sposobu jego pozyskania oraz zmienia się w miarę upływu czasu i warunków jego eksploatacji [4].

Praca niniejsza jest kontynuacją analizy numerycznej procesu spalania w wieloświecowym modelu silnika zasilanym ubogo benzyną, której wyniki przedstawiono w [10]. Obecnie skoncentrowano się na możliwości zastosowania zapłonu wielopunktowego w silniku zasilanym mieszankami ubogimi metanu i powietrza, i wpływie takiego rozwiązania na emisję $\mathrm{NO}$ i $\mathrm{CO}_{2}$.

\section{Model silnika S320ER}

Modelowanie wykonano, opierając się na danych rzeczywistego silnika eksperymentalnego, który powstał na bazie seryjnego, jednocylindrowego silnika wysokoprężnego S320ER (WSW ANDORIA), który po przebudowie pracuje jako silnik o wielopunktowym zapłonie iskrowym [11]. Podstawowe parametry silnika przedstawiono w tabeli 1 .

Zastosowanie w silniku badawczym zapłonu wielopunktowego pozwoliło na spalanie ubogich mieszanek paliw ciekłych i gazowych, o współczynniku nadmiaru powietrza $\lambda \leq 2,0[6,9]$. Rozmieszczenie świec zapłonowych w głowicy silnika przedstawiono na rys. 1 .

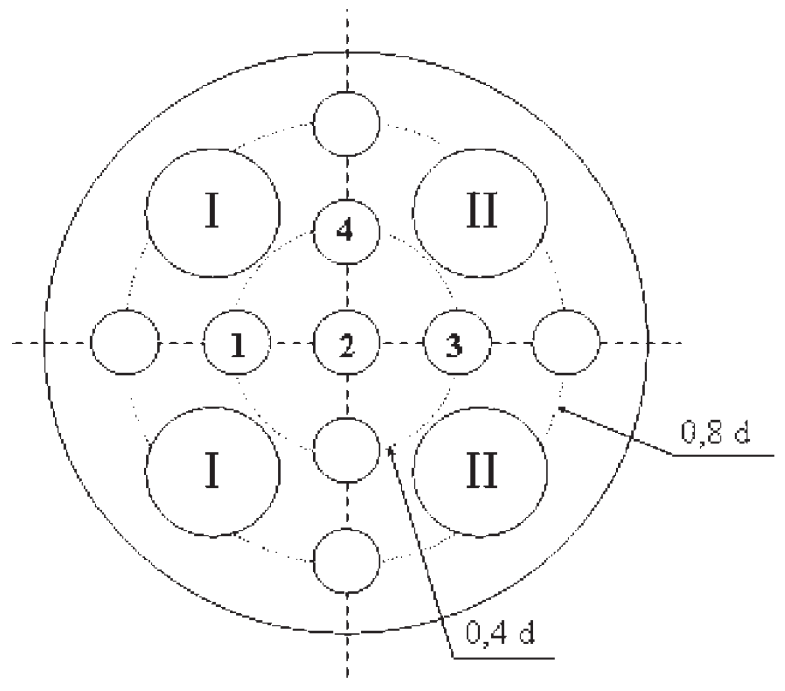

Fig. 1. Spark plug location legend in engine head (I-inlet valves, II-outlet valves, $d$-cylinder bore)

Rys. 1. Rozmieszczenie świec w głowicy (I-zawory dolotowe, II-zawory wylotowe, $d$-średnica cylindra)

Modelowanie numeryczne przeprowadzono za pomocą programu KIVA-3V [2], który pozwala na obliczanie przepływów trójwymiarowych w komorach silników spalinowych o dowolnej geometrii z uwzględnieniem turbulencji oraz wymiany ciepła ze ściankami.

Do celów modelowania, w preprocesorze tego programu, wykonano siatkę geometryczną opisującą komorę spalania silnika rzeczywistego, którą przedstawiono na rys. 2.

\section{Modelowanie procesu spalania}

Symulacje procesu spalania przeprowadzono dla paliwa gazowego, jakim jest metan, przy dwóch wartościach 


\section{Combustion modelling}

The simulation of combustion process was performed for gaseous fuel (methane) at two air excess factor values $(\lambda=1.45$ and 1.8) and three active spark plugs configurations as follows: $2,1-2,1-2-3-4$. Those parameters were derived from earlier numerical and experimental research $[9,11]$.

The chemical reaction of methane combustion model in KIVA-3V takes into account four kinetic reactions and six equilibrium reactions. The first kinetic reaction describes the oxidation of fuel and the following three reactions describe the NO formation according to extended Zeldowicz mechanism $[8,14]$ :

$$
\begin{aligned}
\mathrm{CH}_{4}+2 \mathrm{O}_{2} & \Rightarrow \mathrm{CO}_{2}+2 \mathrm{H}_{2} \mathrm{O}, \\
\mathrm{O}+\mathrm{N}_{2} & \Leftrightarrow \mathrm{N}+\mathrm{NO}, \\
\mathrm{N}+\mathrm{O}_{2} & \Leftrightarrow \mathrm{O}+\mathrm{NO}, \\
\mathrm{N}+\mathrm{OH} & \Leftrightarrow \mathrm{H}+\mathrm{NO} .
\end{aligned}
$$

The equilibrium reactions are [8, 14]:

$$
\begin{gathered}
\mathrm{H}_{2} \Leftrightarrow 2 \mathrm{H}, \\
\mathrm{O}_{2} \Leftrightarrow 2 \mathrm{O}, \\
\mathrm{N}_{2} \Leftrightarrow 2 \mathrm{~N}, \\
\mathrm{O}_{2}+\mathrm{H}_{2} \Leftrightarrow 2 \mathrm{OH}, \\
\mathrm{O}_{2}+2 \mathrm{H}_{2} \mathrm{O} \Leftrightarrow 4 \mathrm{OH}, \\
\mathrm{O}_{2}+2 \mathrm{CO} \Leftrightarrow 2 \mathrm{CO}_{2} .
\end{gathered}
$$

The coefficients of $\mathrm{NO}$ formation kinetic reaction rate are necessary to perform the calculations and they were chosen on the basis of the literature studies [7].

The numerical simulation began at $220^{\circ} \mathrm{CA}$ and finished at $494^{\circ} \mathrm{CA}$, which corresponds to experimental engine camshaft phases, which are inlet valves closure and beginning of outlet valves opening. After earlier optimization the ignition advance angle was set at $353^{\circ} \mathrm{CA}$ for $\lambda=1.45,350^{\circ}$ CA for $\lambda=1.8$.

The results of numerical modeling are presented in graphical form. The distribution of temperature and nitric oxide concentration in the combustion chamber are presented using Tecplot 360 postprocessing software [18]. The courses of pressure, temperature, $\mathrm{NO}$ and $\mathrm{CO}_{2}$ concentration (averaged values for the volume of combustion chamber) in function of crank angle are also presented.

\section{Numerical analysis results}

The following figures depict the distribution of temperature and nitric oxide concentration in the combustion chamber, which occurred for the analyzed air excess factors and active spark plugs configurations. Moreover, courses of pressure, temperature, $\mathrm{NO}$ and $\mathrm{CO}_{2}$ concentration (averaged values for the volume of combustion chamber) in function of crank angle are depicted. The temperature distribution is presented at crank angle equal $5^{\circ}$ after top współczynnika nadmiaru powietrza, a mianowicie $\lambda=1,45$ i 1,8, i dla trzech następujących kombinacji świec zapłonowych: 2, 1-2, 1-2-3-4. Parametry te wybrano, biorąc pod uwagę wcześniejsze prace związane $\mathrm{z}$ modelowaniem oraz eksperymentem $[9,11]$.

Program KIVA-3V w podmodelu reakcji chemicznych procesu spalania paliwa (metan) uwzględnia cztery reakcje kinetyczne i sześć reakcji równowagowych. Pierwsza reakcja kinetyczna określa utlenianie paliwa, natomiast kolejne trzy opisują, zgodnie z rozszerzonym modelem Zeldowicza, mechanizm tworzenia NO $[8,14]$ :

$$
\begin{aligned}
& \mathrm{CH}_{4}+2 \mathrm{O}_{2} \Rightarrow \mathrm{CO}_{2}+2 \mathrm{H}_{2} \mathrm{O}, \\
& \mathrm{O}+\mathrm{N}_{2} \Leftrightarrow \mathrm{N}+\mathrm{NO}, \\
& \mathrm{N}+\mathrm{O}_{2} \Leftrightarrow \mathrm{O}+\mathrm{NO}, \\
& \mathrm{N}+\mathrm{OH} \Leftrightarrow \mathrm{H}+\mathrm{NO} .
\end{aligned}
$$

Reakcje równowagowe to $[8,14]$ :

$$
\begin{gathered}
\mathrm{H}_{2} \Leftrightarrow 2 \mathrm{H}, \\
\mathrm{O}_{2} \Leftrightarrow 2 \mathrm{O}, \\
\mathrm{N}_{2} \Leftrightarrow 2 \mathrm{~N}, \\
\mathrm{O}_{2}+\mathrm{H}_{2} \Leftrightarrow 2 \mathrm{OH}, \\
\mathrm{O}_{2}+2 \mathrm{H}_{2} \mathrm{O} \Leftrightarrow 4 \mathrm{OH}, \\
\mathrm{O}_{2}+2 \mathrm{CO} \Leftrightarrow 2 \mathrm{CO}_{2} .
\end{gathered}
$$

Współczynniki szybkości reakcji kinetycznych tworzenia NO, niezbędne do przeprowadzenia symulacji procesu spalania metanu, zaczerpnięto z literatury [7].

Analizę procesu spalania rozpoczęto od kąta obrotu wału korbowego wynoszącego $220^{\circ} \mathrm{OWK}$, a zakończono na $494^{\circ}$ OWK, co odpowiada fazom rozrządu silnika badawczego, czyli zamknięciu zaworów dolotowych i początkowi otwarcia zaworów wylotowych. Po wcześniejszej optymalizacji kąt wyprzedzenia zapłonu ustalono na poziomie $353^{\circ} \mathrm{OWK}$ dla $\lambda=1,45$ oraz $350^{\circ}$ OWK dla $\lambda=1,8$.

Wyniki modelowania numerycznego przedstawiono $\mathrm{w}$ postaci graficznej. Rozkłady temperatury i tlenku azotu w komorze spalania, będące danymi wyjściowymi z postprocesora GMV [1], zilustrowano w postaci slajdów za pomocą programu graficznego Tecplot 360 [18]. Przedstawiono również przebiegi ciśnienia, temperatury, zawartości NO oraz $\mathrm{CO}_{2}$ (wartości średnie dla całej objętości cylindra) w funkcji kąta obrotu wału korbowego.

\section{Wyniki analizy numerycznej}

Poniższe rysunki przedstawiają rozkład temperatury i tlenku azotu w komorze spalania, jaki wystąpił przy poszczególnych wartościach współczynnika nadmiaru powietrza i dla kolejnych konfiguracji świec zapłonowych oraz przebiegi ciśnienia, temperatury, zawartości $\mathrm{NO}$ oraz $\mathrm{CO}_{2}$ (wartości średnie $\mathrm{z}$ całej objętości cylindra) w funkcji kąta obrotu wału korbowego. Czasoprzestrzenny rozkład temperatury pokazano dla kąta obrotu wału korbowego wynoszącego $5^{\circ}$ po zewnętrznym zwrotnym położeniu tłoka (ZZP), natomiast 
dead center (TDC). The NO distribution is presented at crank angle corresponding with the maximal concentration of this compound.

The temperature distribution as well as pressure and temperature courses (averaged values for the volume of combustion chamber) in function of crank angle for air excess factor $\lambda=1.45$ are depicted in Fig. 3-5.

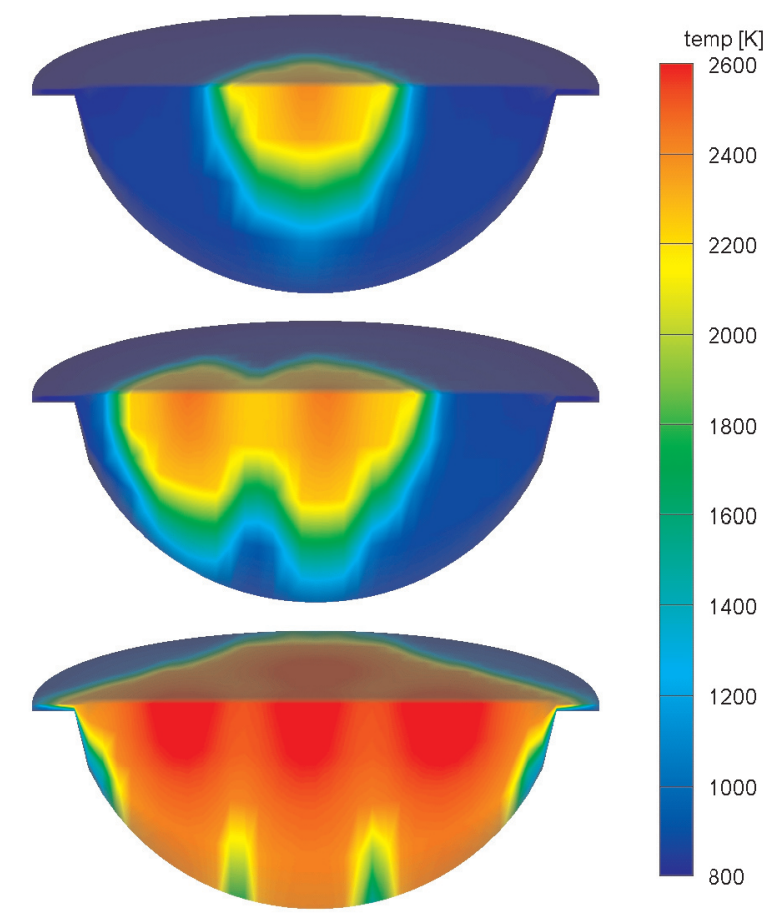

Fig. 3. Temperature distribution for one, two and four spark plugs at $\lambda=1.45$ and $365^{\circ} \mathrm{CA}$

Rys. 3. Rozkład temperatury dla jednej, dwóch i czterech świec zapłonowych przy $\lambda=1,45$ dla $365^{\circ} \mathrm{OWK}$

Figure 3 reveals, that the combustion process was accelerated by increasing the number of active spark plugs. Greater portion of fuel was burnt and temperatures above $2000 \mathrm{~K}$ were reached. Such phenomenon is clearly seen in case of four active spark plugs. In this configuration, the combustion process takes place in almost whole volume of the chamber at $5^{\circ} \mathrm{CA}$ after TDC. The maximal temperature in cylinder reached approx. $2600 \mathrm{~K}$ for four active spark plugs, which is approx. $200 \mathrm{~K}$ more than for one active spark plug.

Figures 4 and 5 depict pressure and temperature courses (averaged values for the volume of combustion chamber) in function of crank angle.

The pressure in the cylinder reaches its maximal value equal $4.2 \mathrm{MPa}$ at $375^{\circ} \mathrm{CA}$ in case of one active spark plug. The increase in the number of active spark plugs to two, causes the $7 \%$ increase in maximal pressure value and the increase in the number of active spark plugs to four, causes the $14 \%$ increase in maximal pressure value.

The maximal pressure values occur earlier than in the configuration with one active spark plug - the differences in crank angle are $4^{\circ}$ and $9^{\circ} \mathrm{CA}$ respectively. It proves that rozkład NO dla kąta odpowiadającego maksymalnemu stężeniu tego związku.

Czasoprzestrzenny rozkład temperatury oraz przebiegi ciśnienia i temperatury (wartości średnie dla całej objętości komory spalania) w funkcji kąta obrotu wału korbowego dla współczynnika nadmiaru powietrza $\lambda=1,45$ przedstawiono na rys. $3-5$.

Z rysunku 3 wynika, że zastosowanie większej liczby świec zapłonowych przyspieszyło proces spalania, ponieważ znacznie większa część ładunku ulega spalaniu i osiąga wysokie temperatury powyżej 2000 K. Najlepiej jest to widoczne dla przypadku czterech świec zapłonowych, gdzie w położeniu tłoka równym $5^{\circ} \mathrm{OWK}$ po ZZP spalanie ładunku odbywa się w znacznej objętości komory spalania. Maksymalna chwilowa temperatura występująca wówczas w cylindrze osiągnęła wartość ok. $2600 \mathrm{~K}$ dla czterech świec zapłonowych i jest to ok. $200 \mathrm{~K}$ więcej niż w przypadku jednej świecy zapłonowej.

Na rysunkach 4 i 5 przedstawiono przebiegi ciśnienia i temperatury (wartości średnie dla całej objętości komory spalania) w funkcji kąta obrotu wału korbowego.

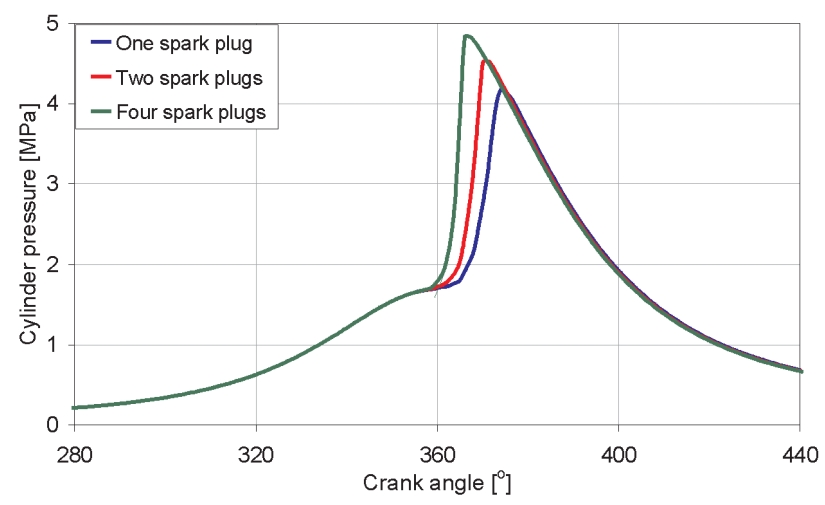

Fig. 4. In cylinder pressure courses for three spark plugs configurations at $\lambda=1.45$

Rys. 4. Przebieg ciśnienia $w$ cylindrze dla trzech konfiguracji świec zaptonowych przy $\lambda=1,45$

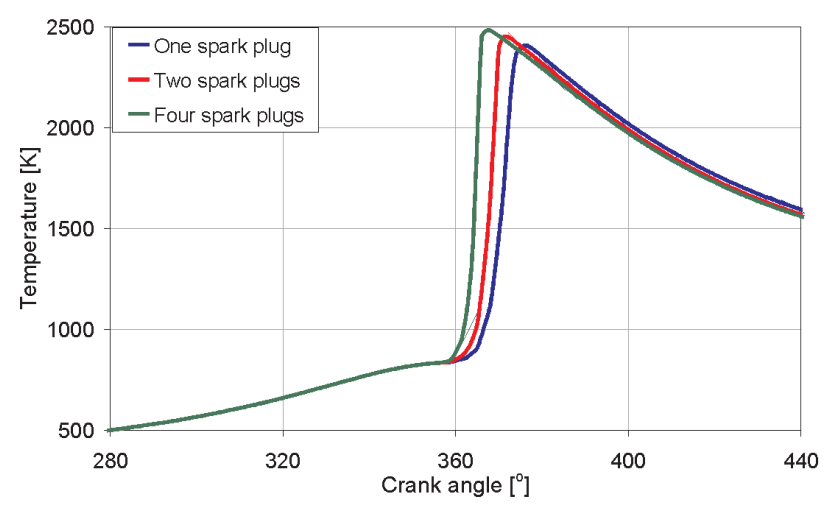

Fig. 5. In cylinder temperature courses for three spark plugs configurations at $\lambda=1.45$

Rys. 5. Przebieg temperatury w cylindrze dla trzech konfiguracji świec zapłonowych przy $\lambda=1,45$

Dla jednej świecy zapłonowej ciśnienie w cylindrze osiąga swą maksymalną wartość równą 4,2 $\mathrm{MPa}$, przy kącie $375^{\circ}$ 
the combustion process was accelerated for the configuration with more spark plugs. It is clearly seen on a chart depicting the pressure growth speed in the cylinder (Fig. 6). For one spark plug, this parameter reaches maximal value of 0.45 $\mathrm{MPa} /{ }^{\circ}$ at $371^{\circ} \mathrm{CA}$, for two spark plugs $\mathrm{dp} / \mathrm{d} \phi$ is $46 \%$ greater and reaches the value of $0.66 \mathrm{MPa} /{ }^{\circ}$ at $368^{\circ} \mathrm{CA}$. In case of four spark plugs, the above mentioned factor value is almost two times more and equals $0.98 \mathrm{MPa} /{ }^{\circ}$ at $364^{\circ} \mathrm{CA}$.

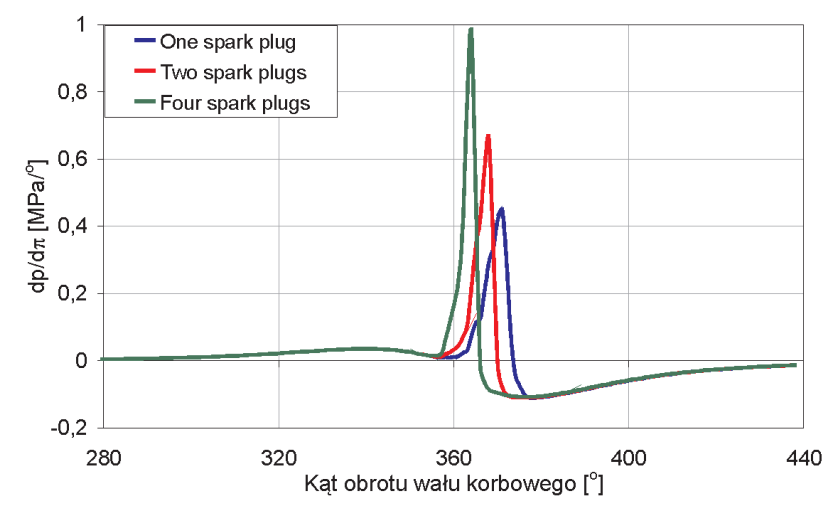

Fig. 6. Pressure growth speed courses in function of crank angle for three spark plugs configurations at $\lambda=1.45$

Rys. 6. Szybkość narastania ciśnienia $w$ funkcji kąta obrotu watu korbowego dla trzech konfiguracji świec zapłonowych przy $\lambda=1,45$

Taking into consideration the above mentioned data, it can be stated that configuration with more active spark plugs is not purposeful. The difference in maximal values of pressure and temperature (Fig. 4 and 5) is not significant. Although the acceleration of combustion process occurs, significant increase in pressure (Fig. 6) can lead to hard and noisy operation, which applies dynamic load to crankshaft and piston.

The modelled engine operation is characterised by significant increase in nitric oxide emission in comparison with single ignition case - Fig. 7 and 8 .

Figure 7 depicts the nitric oxide distribution in the combustion chamber for the subsequent spark plugs configuration. The pictures depict maximal values of nitric oxide concentration and are prepared in the same scale, corresponding with the concentration of for spark plugs configuration. Is can be noticed that increasing the number of active spark plugs significantly increases the NO concentration in the cylinder volume.

For one active spark plug, the nitric oxide concentration (the averaged value for the volume of the combustion chamber - Fig. 8) reached its maximal value equal $2460 \mathrm{ppm}$ at $405^{\circ} \mathrm{CA}$. In case of two ignition points, the NO concentration increased by $30 \%$ up to $3180 \mathrm{ppm}$ at $395^{\circ} \mathrm{CA}$. For four spark plugs, the NO concentration increased by $70 \%$ (4220 ppm) in comparison with one spark plug.

The above analysis proves, that increasing the number of ignition points in case of methane-air mixture of air excess number $\lambda=1.45$ is not favourable. The pressure increase in the cylinder is too big, which can result in very hard engine operation and the nitric oxide emission increases significantly.
OWK. Zwiększenie liczby pracujących świec zapłonowych powoduje przyrost wartości maksymalnej ciśnienia o 7\% dla dwóch świec oraz o 14\% dla czterech świec zapłonowych. Wartości maksymalne ciśnienia pojawiają się wcześniej niż było to dla przypadku jednej świecy, a różnice w kącie obrotu wału korbowego wynoszą odpowiednio $4^{\circ}$ i $9^{\circ}$. Świadczy to o przyspieszeniu procesu spalania dla konfiguracji ze zwiększoną liczbą świec. Dobrze jest to widoczne na wykresie przedstawiającym szybkość narastania ciśnienia $\mathrm{w}$ cylindrze (rys. 6). Dla jednej świecy parametr ten osiąga wartość maksymalną równą $0,45 \mathrm{MPa} /{ }^{\circ}$ przy $371^{\circ} \mathrm{OWK}$, dla dwóch świec dp/d $\phi$ jest już większe o $46 \%$ i wynosi $0,66 \mathrm{MPa} /{ }^{\circ}$ przy $368^{\circ} \mathrm{OWK}$, natomiast dla czterech świec wskaźnik ten wzrósł ponad dwukrotnie, osiągając wartość $0,98 \mathrm{MPa} /{ }^{\circ}$ przy $364^{\circ} \mathrm{OWK}$.

Biorąc pod uwagę powyższe dane i charakterystyki, można zauważyć, że stosowanie większej liczby świec zapłonowych, dla tego przypadku, jest mało zasadne. Różnica w maksymalnych wartościach ciśnienia i temperatury (rys. 4 i 5) jest niewielka, uzyskuje się wprawdzie przyspieszenie procesu spalania, ale dość duży przyrost ciśnienia (rys. 6) może powodować twardą i hałaśliwą pracę silnika, obciążając dynamicznie tym samym układ korbowo-tłokowy silnika.

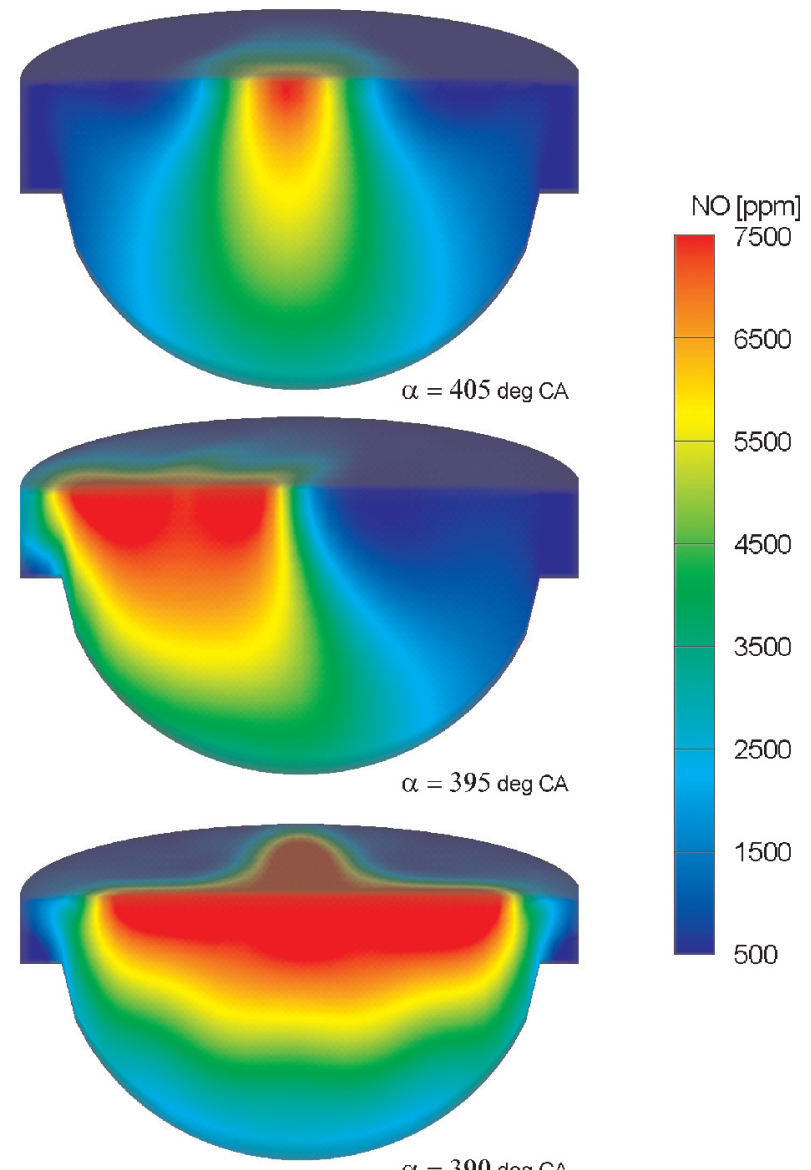

Fig. 7. NO distribution (actual maximum values) for one, two and four spark plugs at $\lambda=1.45$

Rys. 7. Rozkład NO (maksymalne wartości chwilowe) dla jednej, dwóch $i$ czterech świec zapłonowych przy $\lambda=1,45$ 
The chart depicted in Fig. 9 shows the variations of $\mathrm{CO}_{2}$ concentration, which were occurred during modelled operation for three configurations of active spark plugs. The carbon dioxide emission values are mean values, calculated for the whole volume of cylinder. The maximal concentration of this compound was $7 \%$ and was obtained at different crank angles depending on the number of active spark plugs. With the increase of active spark plugs, the maximal concentration of $\mathrm{CO}_{2}$ was obtained faster. In case of one active spark plug, the maximal concentration was observed at $380^{\circ} \mathrm{CA}$. For two active spark plugs it was observed at $374^{\circ} \mathrm{CA}$, and for four spark plugs it was at $370^{\circ} \mathrm{CA}$.

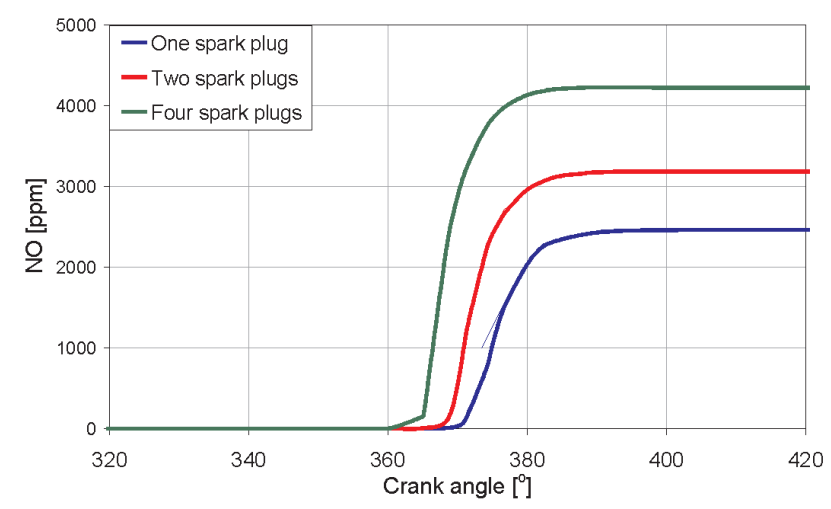

Fig. 8. Variations of NO concentration (mean values for cylinder volume) for $\lambda=1.45$

Rys. 8. Zmiany stężenia NO (wartości średnie dla całej objętości cylindra) dla $\lambda=1,45$

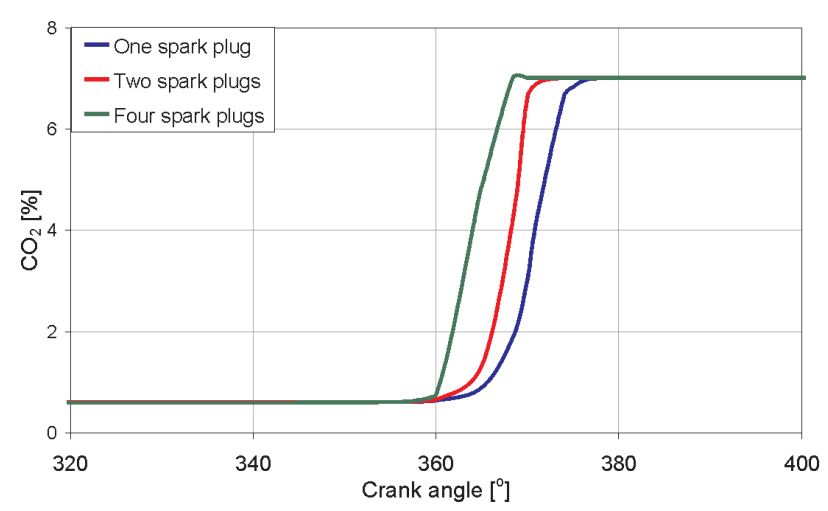

Fig. 9. Variations of $\mathrm{CO}_{2}$ concentration (mean values for cylinder volume) for $\lambda=1.45$

Rys. 9. Zmiany stężenia $\mathrm{CO}_{2}$ (wartości średnie dla całej objętości cylindra) dla $\lambda=1,45$

The next objective of this paper was the modelling of very lean methane-air mixture combustion (air excess factor 1.8).

Figures 10 to 12 depict temperature distribution as well as pressure and temperature courses (averaged values for the volume of combustion chamber) in function of crank angle.

Leaning the mixture up to $\lambda=1.8$ caused decrease of maximal temperature values in comparison with the prior
Praca modelu silnika przy zwiększonej liczbie świec zapłonowych charakteryzuje się również znacznym wzrostem emisji tlenku azotu, w porównaniu do zapłonu jednopunktowego - rys. 7 i 8 . Na rysunku 7 przedstawiono czasoprzestrzenny rozkład tlenku azotu w komorze spalania dla kolejnych konfiguracji świec zapłonowych. Slajdy przedstawiają maksymalne wartości chwilowe stężenia tlenku azotu i są wykonane w jednakowej skali, odpowiadającej stężeniu dla konfiguracji czteroświecowej. Można zauważyć, że wzrost liczby czynnych świec zapłonowych znacząco zwiększa koncentrację NO w objętości cylindra.

Dla jednej świecy zapłonowej stężenie tlenku azotu (wartość średnia dla całej objętości komory spalania rys. 8) osiągnęło swą wartość maksymalną równą 2460 ppm przy kącie $405^{\circ} \mathrm{OWK}$, natomiast dla dwóch punktów zapłonu stężenie to wzrosło już o $30 \%$ do wartości 3180 ppm przy $395^{\circ}$ OWK. Przypadek czterech świec zapłonowych to już wzrost stężenia NO o ponad 70\% (4220 ppm) w porównaniu do układu jednoświecowego.

Analiza powyższa wykazała, że zwiększanie liczby punktów zapłonu mieszanki metanu z powietrzem o $\lambda=1,45$ nie jest korzystne. Przyrost ciśnienia w cylindrze jest zbyt duży, co może powodować twardą pracę silnika, a przede wszystkim bardzo znacząco rośnie emisja tlenku azotu.

Wykres z rysunku 9 przedstawia zmiany stężenia $\mathrm{CO}_{2}$ jakie wystąpiły podczas pracy modelu silnika dla trzech konfiguracji świec. Wartości emisji $\mathrm{CO}_{2}$ są wartościami średnimi, liczonymi dla całej objętości cylindra. Maksymalne stężenie tego składnika wyniosło 7\% i, w zależności od liczby świec zapłonowych, zostało osiągnięte przy różnych kątach obrotu wału korbowego. Oczywiście im więcej pracujących świec, tym $\mathrm{CO}_{2}$ szybciej osiągało swe maksymalne stężenie i dla jednej świecy wystąpiło ono przy $380^{\circ} \mathrm{OWK}$, dla dwóch świec przy $374^{\circ} \mathrm{OWK}$, a dla czterech świec przy $370^{\circ}$ OWK.

Następnym punktem pracy było modelowanie procesu spalania bardzo ubogiej mieszanki metanu z powietrzem o współczynniku nadmiaru powietrza $\lambda=1,8$.

Na rysunkach 10-12 przedstawiono czasoprzestrzenny rozkład temperatury oraz przebiegi ciśnienia i temperatury (wartości średnie dla całej objętości komory spalania) w funkcji kąta obrotu wału korbowego.

Zubożenie mieszanki do $\lambda=1,8$ spowodowało zmniejszenie maksymalnych wartości temperatury, w porównaniu do poprzednich nastaw współczynnika nadmiaru powietrza. Widać wyraźnie (rys. 10), że przy tym samym kącie obrotu wału korbowego obszar palącego się ładunku ma znacznie niższe temperatury niż miało to miejsce dla $\lambda=1,45$ (rys. 3).

Stwierdzono również spadek maksymalnych wartości ciśnienia dla każdego z modelowanych układów świec zapłonowych - rys. 11. Dla zapłonu jednoświecowego ciśnienie spadło do wartości 3,5 MPa przy $377^{\circ} \mathrm{OWK}$, dla dwóch świec do 4,0 MPa przy $371^{\circ} \mathrm{OWK}$, a dla czterech świec do $4,4 \mathrm{MPa}$ przy $365^{\circ} \mathrm{OWK}$.

Rozpatrując wykres zmian temperatury (rys. 12), można zaobserwować również spadek jej maksymalnych war- 
settings of air excess factor. It is clearly seen (Fig. 10), that at the same crank angle, the temperature of the volume of burning mixture is significantly lower than in case of $\lambda=1.45$ (Fig. 3).

The decrease of maximal pressure values for each of the modelled active spark plug configurations was stated Fig. 11. In case of single spark plug, the pressure decreased down to $3.5 \mathrm{MPa}$ at $377^{\circ} \mathrm{CA}$, in case of two spark plugs it decreased to $4.0 \mathrm{MPa}$ at $371^{\circ} \mathrm{CA}$, and for four spark plugs it decreased to $4.4 \mathrm{MPa}$ at $365^{\circ} \mathrm{CA}$.

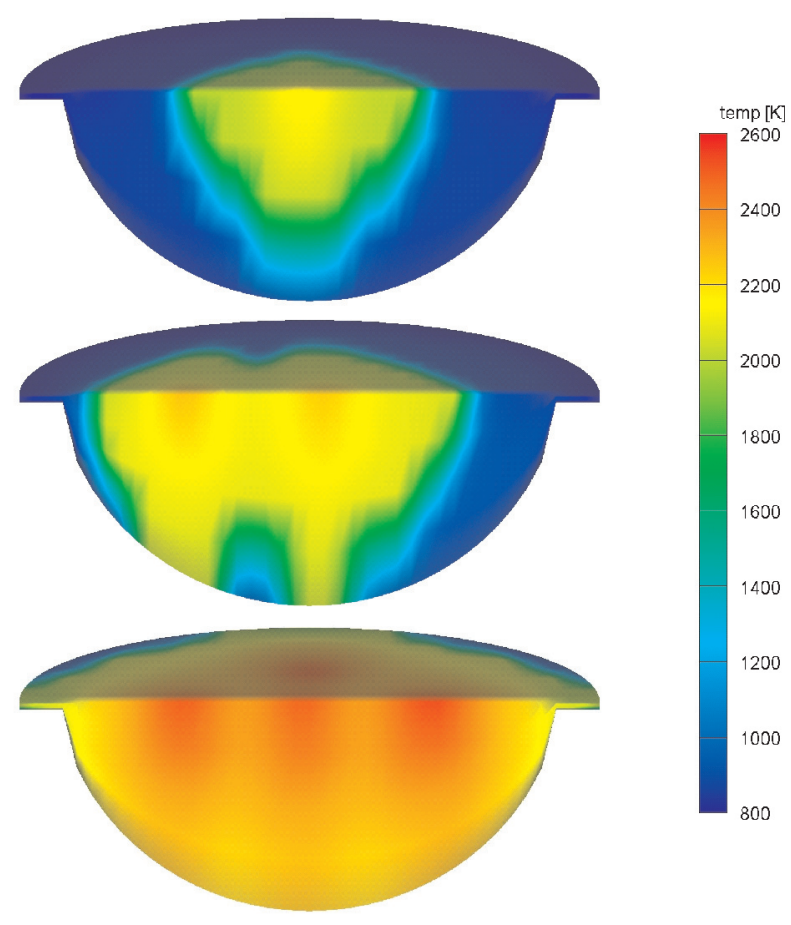

Fig. 10. Temperature distribution for one, two and four spark plugs at $\lambda=1.8$ and $365^{\circ} \mathrm{CA}$

Rys. 10. Rozkład temperatury dla jednej, dwóch i czterech świec zapłonowych przy $\lambda=1,8$ dla $365^{\circ} \mathrm{OWK}$

Analysis of temperature courses (Fig. 12) also reveals the decrease of maximal temperature value in comparison with the previous case (Fig. 5). Simultaneously, differences between maximal values of temperature as well as pressure are significantly greater that in case of $\lambda=1.45$. Pressure for two active spark plugs increased by $14 \%$ in comparison with single ignition point and for four spark plugs the increase was $26 \%$. The increase in temperature was 5 and $7 \%$ respectively.

The conclusion from the above analysis is as follows: more ignition points is purposeful in case of such lean mixture. The reason of such conclusion is the improvement of basic engine work parameters and increase in pressure growth speed, which in case of very lean mixtures, is favourable because such mixtures are characterized by very slow combustion. The pressure growth in the cylinder (Fig. 13) for more ignition points is not such rapid as in case of air excess factor $\lambda=1.45$. tości w porównaniu do poprzedniego przypadku (rys. 5). Równocześnie różnice pomiędzy wartościami maksymalnymi temperatury i ciśnienia są znacznie większe niż dla $\lambda=1,45$. W porównaniu do układu jednoświecowego ciśnienie dla dwóch świec wzrosło o $14 \%$, dla czterech świec o $26 \%$, natomiast temperatura odpowiednio 5 oraz $7 \%$.

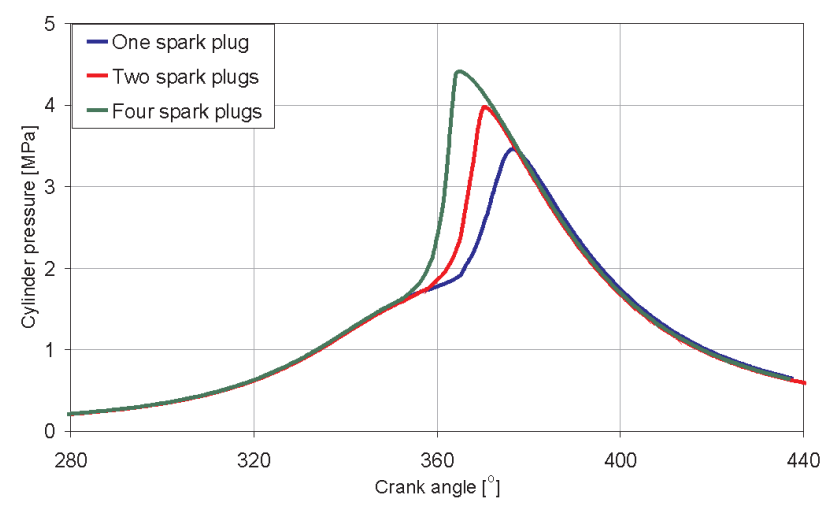

Fig. 11. In cylinder pressure courses for three spark plugs configurations at $\lambda=1.8$

Rys. 11. Przebieg ciśnienia $w$ cylindrze dla trzech konfiguracji świec zapłonowych przy $\lambda=1,8$

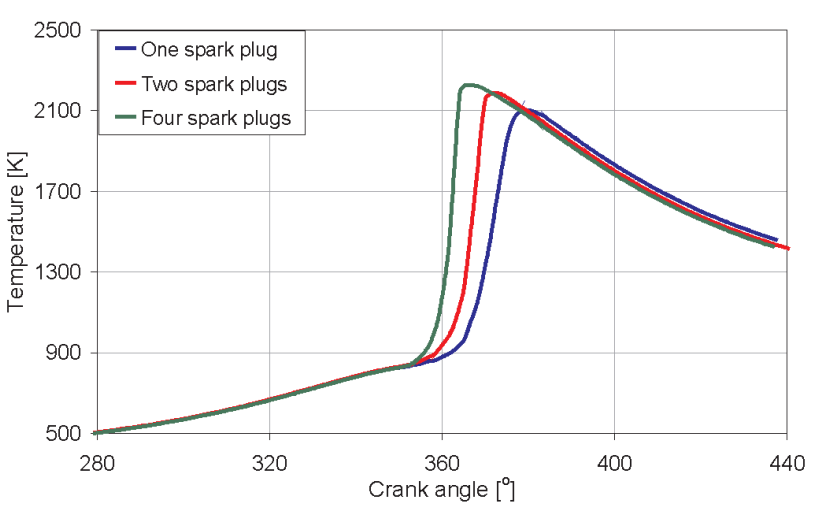

Fig. 12. In cylinder temperature courses for three spark plugs configurations at $\lambda=1.8$

Rys. 12. Przebieg temperatury $w$ cylindrze dla trzech konfiguracji świec zaptonowych przy $\lambda=1,8$

W wyniku powyższej analizy nasuwa się spostrzeżenie, że dla tak ubogiej mieszanki zasadne jest zastosowanie większej liczby świec zapłonowych. Otrzymujemy bowiem poprawę podstawowych parametrów pracy silnika, zwiększenie szybkości narastania ciśnienia, co przy mieszankach bardzo ubogich jest korzystne ze względu na ich charakterystyczne powolne, a wręcz przewlekłe spalanie. Przyrost ciśnienia w cylindrze (rys. 13) dla zwiększonej liczby punktów zapłonu nie jest już tak gwałtowny jak dla poprzedniego składu mieszanki.

Szybkość narastania ciśnienia najwyższą swą wartość równą $0,59 \mathrm{MPa} /{ }^{\circ}$ osiągnęła dla układu czteroświecowego, co jest wartością prawie trzykrotnie większą od przyrostu ciśnienia dla jednej świecy - 0,2 $\mathrm{MPa} /{ }^{\circ}$. Ze względu na wymieniony wskaźnik, najkorzystniejszą dla pracy modelu silnika wydaje się konfiguracja dwuświecowa, ponieważ dla 
The maximal value of pressure growth speed equal 0.59 $\mathrm{MPa} /{ }^{\circ}$ is obtained for the configuration with four active spark plugs, which is almost three times as much as for the configuration with single ignition point $\left(0.2 \mathrm{MPa} /{ }^{\circ}\right)$. In terms of pressure growth speed, the configuration with two active spark plugs seems to be the most favourable one. For this configuration $\mathrm{dp} / \mathrm{d} \phi$ equals $0.43 \mathrm{MPa} /{ }^{\circ}$ and is comparable with pressure growth speed of one spark plug configuration at $\lambda=1.45$ (Fig. 6) - this configuration was the optimal one.

The next goal of the paper was the numerical analysis of nitric oxide formation. The results of above mentioned analysis (Fig. 14 and 15) also showed the increase of NO emission while increasing the number of active spark plugs, though the maximal values of nitric oxide concentration are several times lower in comparison with mixture of $\lambda=1.45$. The NO concentration was growing from approx. $45 \mathrm{ppm}$ in case of one spark plugs up to 560 ppm for four spark plugs. In case of two spark plugs, the NO concentration value was 285 ppm (Fig. 15). The above mentioned values are average values for the temporary cylinder volume.
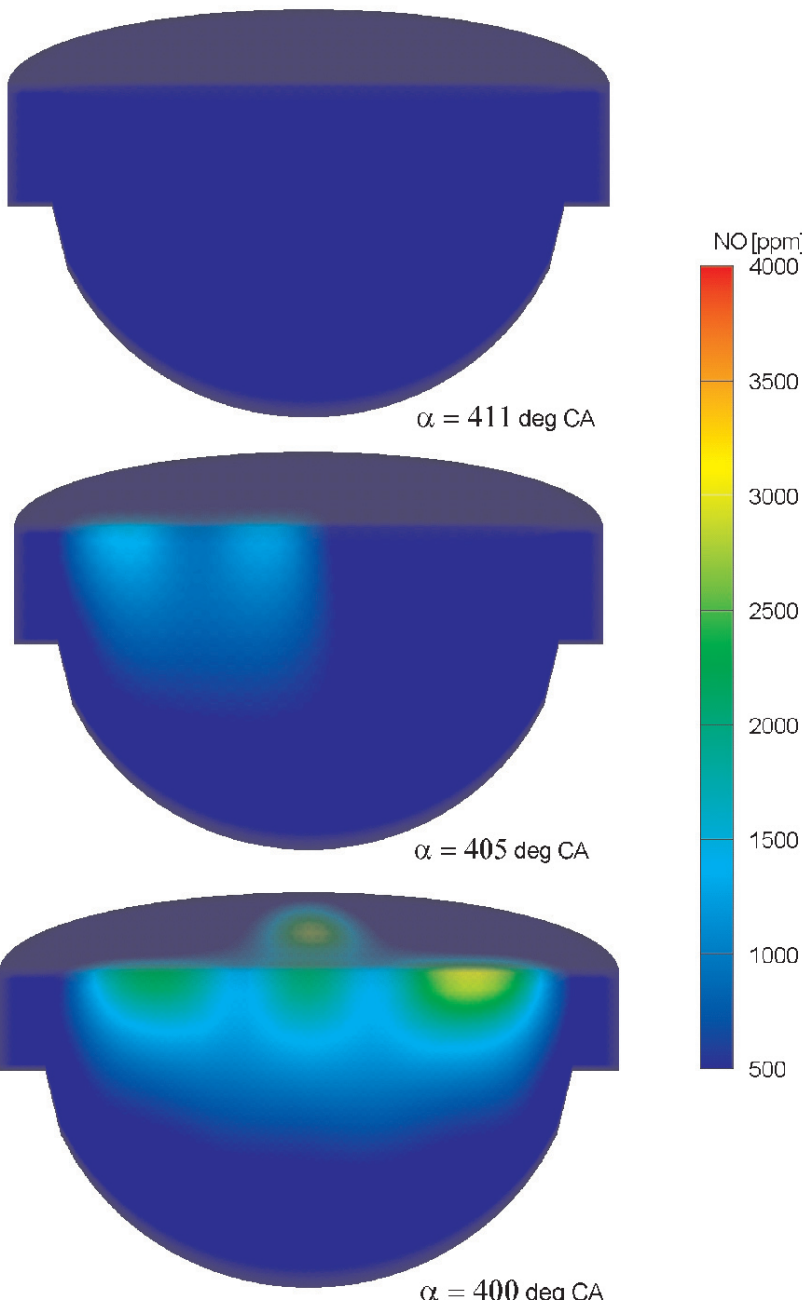

Fig. 14. NO distribution (actual maximum values) for one, two and four spark plugs at $\lambda=1.8$

Rys. 14. Rozktad NO (maksymalne wartości chwilowe) dla jednej, dwóch i czterech świec zaplonowych przy $\lambda=1,8$ niej wartość $\mathrm{dp} / \mathrm{d} \phi$, równa $0,43 \mathrm{MPa} /{ }^{\circ}$, jest porównywalna z szybkością narastania ciśnienia dla jednoświecowego przypadku modelu silnika przy $\lambda=1,45$ (rys. 6), która to konfiguracja była wówczas optymalna.

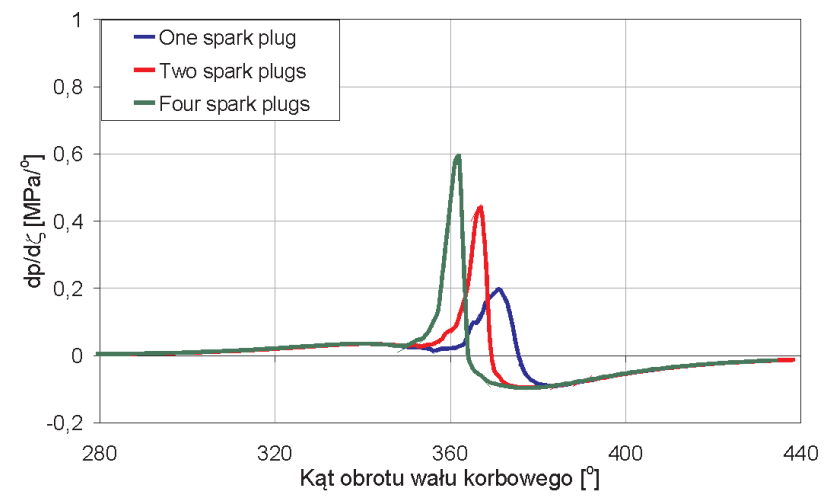

Fig. 13. Pressure growth speed courses in function of crank angle for three spark plugs configurations at $\lambda=1.8$

Rys. 13. Szybkość narastania ciśnienia $w$ funkcji kąta obrotu wału korbowego dla trzech konfiguracji świec zapłonowych przy $\lambda=1,8$

Kolejnym etapem pracy było przeprowadzenie analizy numerycznej tworzenia się tlenku azotu. Wyniki tej analizy (rys. 14 i 15) również wykazały wzrost emisji NO wraz ze wzrostem liczby czynnych świec zapłonowych, choć wartości maksymalne stężenia tlenku azotu są kilkukrotnie mniejsze $\mathrm{w}$ porównaniu do spalania mieszanki o $\lambda=1,45$. Wartość stężenia NO rosła od ok. 45 ppm dla jednej świecy, poprzez 285 ppm dla dwóch świec, aż do wartości 560 ppm otrzymanej dla konfiguracji z czterema świecami zapłonowymi (rys. 15). Wszystkie podane wartości są wartościami średnimi dla chwilowej objętości cylindra.

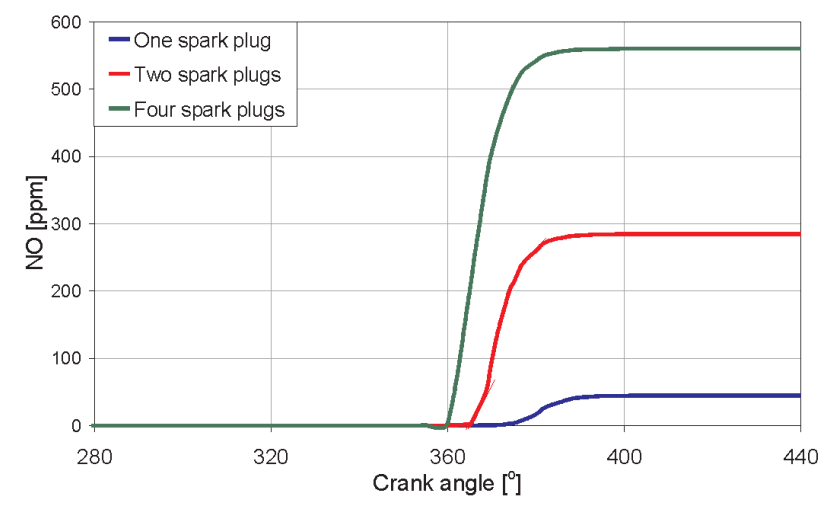

Fig. 15. Variations of NO concentration (mean values for cylinder volume) for $\lambda=1.8$

Rys. 15. Zmiany stężenia NO (wartości średnie dla całej objętości cylindra) dla $\lambda=1,8$

Zwiększenie liczby świec zapłonowych do dwóch powoduje wprawdzie ponad sześciokrotny przyrost NO, w porównaniu do układu z jedną świecą, ale zawartość tlenku azotu na poziomie niższym od 300 ppm jest wynikiem zadowalającym. Wynik ten jest na poziomie stężenia $\mathrm{NO}_{\mathrm{x}} \mathrm{w}$ 
Increasing the number of active spark plugs to two causes the six times increase in NO concentration in comparison with single ignition point but the NO concentration is at the level lower than $300 \mathrm{ppm}$, which is acceptable. This result is at the level of $\mathrm{NO}_{\mathrm{x}}$ concentration in the $8 \mathrm{~A} 20 \mathrm{G}$ engine manufactured by H.Cegielski-Poznań S.A. fuelled by biogas of approx. $65 \% \mathrm{CH}_{4}$ containment and operating at $\lambda=1.45$ [5]. It has to be mentioned that the KIVA software generates nitric oxide NO concentration and the main containment of $\mathrm{NO}_{\mathrm{x}}$ measured in the exhaust duct of the test engine is nitric oxide NO. The other component is $\mathrm{NO}_{2}$, which occurs at low concentration.

Fuelling the engine model with mixture of $\lambda=1.8$ results in the decrease of $\mathrm{CO}_{2}$ emission by approx. $17 \%$ in comparison with the other analyzed mixture composition. The carbon dioxide concentration was $5.8 \%$ (Fig. 16).

The maximal values of $\mathrm{CO}_{2}$ concentration were obtained earlier along with increasing the number of ignition points. The difference in crank angle is $19^{\circ}$ for two spark plugs and $24^{\circ}$ for four spark plugs in comparison with single spark plug.

The obtained results of $\mathrm{CO}_{2}$ formation at $\lambda=1.8$ are at significantly lower level than the containment of this compound in the exhaust gases of earlier mentioned 8A20G engine, which was operating in the sewage treatment plant WARTA S.A. in Częstochowa. The carbon dioxide emission for this engine was at the level of $10 \%$ [5], so more than $70 \%$ greater than the results of numerical analysis.

\section{Conclusions}

The results of $3 \mathrm{D}$ modelling of methane combustion in multipoint ignition engine showed, that using more ignition points in case of very lean mixtures $(\lambda=1.8)$ can be purposeful.

Multipoint ignition in case of richer mixtures $(\lambda=$ $=1.45$ ) caused very significant increase in NO emission, which gained even $70 \%$ for four spark plugs. The difference in maximal values of pressure and temperature was insignificant. High values of pressure growth speed (maximal value of $1 \mathrm{MPa} /{ }^{\circ}$ ) can lead to noisy and hard engine operation.

The configuration with two active spark plugs turned out to be the most favourable in case of air excess factor equal 1.8. More than two times increase in pressure growth speed up to value $0.43 \mathrm{MPa} /{ }^{\circ}$ at $367^{\circ} \mathrm{CA}$ was obtained in comparison with single spark plug. The differences were not such rapid as in the previous case. The obtained value of $\mathrm{dp} / \mathrm{d} \phi$ is very similar to pressure growth speed $\left(0.45 \mathrm{MPa} /{ }^{\circ}\right)$ that occurred for mixture of $\lambda=1.45$. The maximal values of pressure and temperature for the configuration with two spark plugs at $\lambda=1.8$ and the single spark plug configuration at $\lambda=1.45$ are similar to each other. It can be stated that using two ignition points in case of methane-air mixture of $\lambda=$ $=1.8$ generates similar engine work parameters as in the case of fuelling the engine with richer mixtures of $\lambda=1.45$. The differences that occur are favourable for the leaner mixture and two spark plugs - almost nine times lower NO emission and $20 \%$ lower $\mathrm{CO}_{2}$ concentration in exhaust gases. spalinach rzeczywistego silnika 8A20G, produkcji H.Cegielski-Poznań S.A., zasilanego biogazem o zawartości $\mathrm{CH}_{4}$ na poziomie ok. $65 \%$, a pracującego przy $\lambda \approx 1,45$ [5]. Należy tutaj nadmienić, że program KIVA w swych wynikach podaje zawartość NO, jednak głównym składnikiem związków $\mathrm{NO}_{x}$ mierzonych w kanale wylotowym silnika jest właśnie tlenek azotu; towarzyszący mu dwutlenek azotu $\mathrm{NO}_{2}$ osiąga niewielkie stężenie.

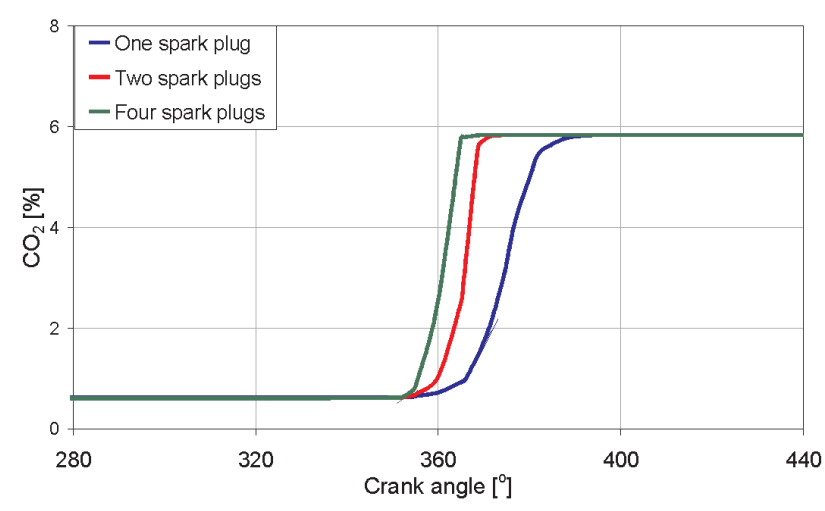

Fig. 16. Variations of $\mathrm{CO}_{2}$ concentration (mean values for cylinder volume) for $\lambda=1.8$

Rys. 16. Zmiany stężenia $\mathrm{CO}_{2}$ (wartości średnie dla całej objętości cylindra) dla $\lambda=1,8$

Zasilanie modelu silnika mieszanką o $\lambda=1,8$ skutkuje spadkiem emisji $\mathrm{CO}_{2}$ o ok. $17 \%$, w porównaniu do poprzedniego przypadku składu mieszanki. Stężenie dwutlenku węgla osiągnęło wartość równą 5,8\% (rys. 16).

Im więcej punktów zapłonu, tym $\mathrm{CO}_{2}$ osiąga wcześniej swoje maksymalne stężenie i w porównaniu do układu $\mathrm{z}$ jedną świecą, różnica w kącie obrotu wału korbowego wynosi odpowiednio $19^{\circ}$ dla dwóch świec oraz $24^{\circ}$ dla czterech świec zapłonowych.

Otrzymane wyniki analizy tworzenia $\mathrm{CO}_{2}$ przy $\lambda=1,8$ są na znacznie niższym poziomie niż zawartości tego składnika w spalinach wspomnianego wcześniej silnika 8A20G, który pracował w Oczyszczalni Ścieków WARTA S.A. w Częstochowie. Emisja dwutlenku węgla dla tego silnika była na poziomie $10 \%$ [5], więc o ponad $70 \%$ więcej niż otrzymano podczas analizy numerycznej.

\section{Podsumowanie}

Wyniki trójwymiarowego modelowania procesu spalania metanu w silniku z zapłonem wielopunktowym wykazały, że celowe może być zastosowanie większej liczby punktów zapłonu podczas spalania mieszanki o znacznym zubożeniu $-\lambda=1,8$.

Zastosowanie zapłonu wielopunktowego przy mieszankach bogatszych $(\lambda=1,45)$ powodowało bardzo duży wzrost emisji NO w spalinach, sięgający nawet $70 \%$ dla czterech świec zapłonowych. Natomiast różnica w maksymalnych wartościach ciśnienia i temperatury była niewielka, a dość duże wartości szybkości narastania ciśnienia, wynoszące maksymalnie ok. $1 \mathrm{MPa} /{ }^{\circ}$, mogą przyczyniać się do zbyt hałaśliwej i twardej pracy silnika. 
Two spark plugs in cylinder allow to sustain the basic engine work parameters while fuelling it with mixture of more than $20 \%$ higher air excess factor. Simultaneously, significantly lower nitric oxide and carbon dioxide emission is obtained.

Paper reviewed

\section{Nomenclature/Skróty i oznaczenia}

OWK crank angle degree/kat obrotu watu korbowego

$\lambda \quad$ air excess number/współczynnik nadmiaru powietrza

NO nitric oxide/tlenek azotu

$\mathrm{CO}_{2} \quad$ carbon dioxide/dwutlenek wegla

$\mathrm{dp} / \mathrm{d} \phi \quad$ pressure growth speed/szybkość narastania ciśnienia
Dla $\lambda=1,8$ najkorzystniejsza okazała się konfiguracja dwóch świec zapłonowych. W porównaniu z układem jednoświecowym otrzymano ponad dwukrotny przyrost szybkości narastania ciśnienia, do wartości $0,43 \mathrm{MPa} /{ }^{\circ} \operatorname{przy} 367^{\circ} \mathrm{OWK}$, a zmiany te nie były już tak gwałtowne jak w poprzednim przypadku. Uzyskana wartość dp/d $\phi$ jest bardzo zbliżona do przyrostu ciśnienia $\left(0,45 \mathrm{MPa} /{ }^{\circ}\right)$, jaki wystąpił przy spalaniu mieszanki o $\lambda=1,45$. Równocześnie wartości maksymalne ciśnienia i temperatury dla dwuświecowej konfiguracji przy $\lambda=1,8$ i dla układu jednoświecowego przy $\lambda=1,45$ są do siebie zbliżone. Można stwierdzić, że zastosowanie dwóch punktów zapłonu, podczas spalania mieszanki metanu $\mathrm{z}$ powietrzem o $\lambda=1,8$, daje zbliżone parametry pracy modelu silnika do przypadku zasilania mieszanką bogatszą o $\lambda=1,45$. Różnice, jakie występują, przemawiające na korzyść mieszanki uboższej i dwóch świec zapłonowych, to prawie dziewięciokrotnie mniejsza emisja NO oraz zmniejszona o $20 \%$ zawartość $\mathrm{CO}_{2}$ w spalinach modelu silnika.

\section{Bibliography/Literatura}

[1] Abraham J., Magi V.: GMV, Mesh Viewer General, Los Alamos National Laboratory LA-UR-952986, March 1995.

[2] Amsden A.A.: KIVA-3V: A block-structured computer program for 3-D fluid flows with valves, chemical reactions, and fuel sprays, Los Alamos National Laboratory, Group T-3, March 1997.

[3] Badyda K., Lewandowski J.: Obciążenie środowiska naturalnego wynikające $\mathrm{z}$ wykorzystania gazu w rozproszonych siłowniach, Materiały międzynarodowej konferencji „Ekologiczne aspekty wytwarzania energii elektrycznej”, Warszawa 2001.

[4] Badyda K.: Możliwości zagospodarowania gazu kopalnianego w Polsce dla celów energetycznych, Energetyka, czerwiec 2008.

[5] Cupiał K., Dużyński A., Grzelka J.: Wpływ katalizatora oksydacyjnego na toksyczność spalin silnika gazowego 8A20G, V Międzynarodowa Konferencja Naukowa „Silniki gazowe 2000 - konstrukcja, badania, eksploatacja”. Politechnika Częstochowska 2000.

[6] Cupiał K., Kociszewski A., Jamrozik A.: Multipoint spark ignition engine operating on lean mixture, Teka Komisji Motoryzacji i Energetyki Rolnictwa, PAN oddział w Lublinie, tom III, Lublin 2003, s. 70-78.

[7] Jamrozik A.: Modelowanie procesu tworzenia tlenku azotu w komorze spalania gazowego silnika. VII Międzynarodowa Konferencja Naukowa „Silniki gazowe 2006 - konstrukcja, badania, eksploatacja, paliwa odnawialne". Zeszyty Naukowe Politechniki Częstochowskiej, Mechanika 26, 2006.

Mr. Arkadiusz Kociszewski, DEng. - doctor in the Faculty of Mechanical Engineering and Computer Science of Częstochowa University of Technology. Dr inż. Arkadiusz Kociszewski - adiunkt na Wydziale Inżynierii Mechanicznej i Informatyki Politechniki Częstochowskiej.

e-mail: kocisz@imc.pcz.czest.pl

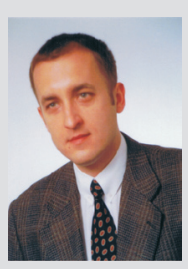

[8] Kesler M., Leżański T., Rychter T., Wolański P.: System spalania o zapłonie strumieniowym - analiza teoretyczna i badania silnikowe, International Scientific Conference on Internal Combustion Engines KONES'93, Gdańsk - Jurata 1993.

[9] Kociszewski A., Cupiał K., Jamrozik A.: Możliwości spalania gazowych mieszanek zubożonych w silniku ZI, Journal of KONES, Internal Combustion Engines, Vol. 11, No. 1-2, 2004.

[10] Kociszewski A., Jamrozik A., Sosnowski M., Tutak W.: Simulation of combustion in multi spark plug engine in KIVA-3V, Silniki Spalinowe/Combustion Engines, Mixture Formation Ignition \& Combustion, 2007-SC2, 2007.

[11] Kociszewski A.: Spalanie mieszanek homogenicznych w silniku tłokowym z zapłonem wielopunktowym, Praca doktorska, Politechnika Częstochowska 2004.

[12] Meyer R.C., Meyers D.P., King S.R., Liss W.E.: Effects of spark plug number and location in natural gas engines, Journal of Engineering for Gas Turbines and Power, Vol. 114, 1992.

[13] Quader A.A.: Lean combustion and the misfire limit in spark ignition engines, SAE Paper 741055, 1974.

[14] Rychter T., Teodorczyk A.: Modelowanie matematyczne roboczego cyklu silnika tłokowego, Państwowe Wydawnictwo Naukowe, Warszawa 1990.

[15] Sosnowski M.: Modelowanie i analiza przebiegu wyładowania iskrowego w silniku z zapłonem wymuszonym, Praca doktorska, Częstochowa 2008.

[16] Sosnowski M.: Modelling of Combustion in SI Engine Using Different Ignition Models, Teka Komisji Motoryzacji PAN, 2008

[17] Sosnowski M.: Modelowanie procesu inicjacji zapłonu w silniku ZI, Zeszyty Naukowe Politechniki Opolskiej nr 301, Mechanika z. 80, 2005.

[18] Tecplot Inc.: Tecplot 360 User's Manual, Bellevue 2006.

[19] Yamamoto H., Horita S., Matsuoka T.: Surrounding combustion process (SCP) - new concept for lean burn engine, SAE Paper 920058, 1992. 